\title{
Development of commercial products from cluster beans
}

\author{
- L. Aiswarya and Suma Divakar* \\ College of Agriculture, Vellayani, Thiruvananthapuram (Kerala) India \\ (Email: divakarsuma67@gmail.com) \\ *Author for Correspondence \\ Research chronicle : Received : 27.04.2020; Revised : 18.05.2020; Accepted : 25.05.2020
}

SUMMARY:

Cluster bean is a very familiar produce in the Indian vegetable markets. Eighty per cent of the world's cluster bean is cultivated in our country, as the crop can tolerate both frequent rainfalls and arid conditions. However, this vegetable is comparatively less used in conventional cuisine. The promotion of cluster bean consumption through development commercial products would have great scope in the market. Three commercial products of cluster beans were developed namely bread spread, chutney powder and ready-to-cook curry mix. Five different formulations were worked out with various ingredients in different proportions. The best formulations were selected with respect to parameters such as appearance, colour, flavour texture, taste and overall acceptability by a sensory panel comprising of ten members. The products have scope to be commercialised in urban markets.

KEY WORDS : Commercial products, Cluster beans

How to cite this paper : Aiswarya, L. and Divakar, Suma (2020). Development of commercial products from cluster beans. Internat. J. Proc. \& Post Harvest Technol., 11(1) : 12-17. DOI: 10. 15740/HAS/IJPPHT/11.1/ 12-17. Copyright@ 2020: Hind Agri-Horticultural Society. 